\title{
PENERAPAN STRATEGI PEMBELAJARAN INKUIRI BERBANTUAN ALAT PERAGA "DULOK KUMISAN" DALAM MENINGKATKAN PEMAHAMAN MATEMATIS PESERTA DIDIK
}

\author{
Rina Kurnia, Yeti Nurhayati \\ PGSD FKIP Universitas Langlangbuana, \\ rinakurnia1751990.rk@gmail.com
}

\begin{abstract}
One of the basic competencies that must be mastered by the fifth grade students is a mathematical understanding of the volume of cubes and cuboids. Observations show that most of the fifth grade students at SDN Margahayu 08 in the 2018/2019 academic year demonstrate low mathematical understanding. This study aims to apply the inquiry learning strategy assisted by the "Dulok Kumisan", a teaching aid in improving mathematical understanding. The research method used is the quasi-experimental research design with nonequivalent control group design. The instruments used were description tests and observation sheets of learning implementation. The first hypothesis testing used the average difference test (data comes from normal and homogeneous distributions) while the second hypothesis was tested with the Mann Whitney U Test because normality is not met but comes from homogeneous variance. The results showed that the mathematical understanding of experimental group students who applied inquiry learning strategies assisted with the "Dulok Kumisan" teaching aid was better than that of the control class that used conventional learning methods. There was an improvement in mathematical understanding of the fifth grade students at SDN Margahayu 08 on cube and cuboid volume after the inquiry learning strategy was used. Thus, the inquiry learning strategy assisted by the "Dulok Kumisan" teaching aid can be applied to improve mathematical understanding.
\end{abstract}

Keywords: Inquiry Learning Strategy, Mathematical Understanding, Cube and Cuboid Volume Teaching Aids

\begin{abstract}
Abstrak
Salah satu kompetensi dasar yang harus dikuasai oleh peserta didik sekolah dasar kelas V yaitu pemahaman matematis pada pokok bahasan volume kubus dan balok. Berdasarkan hasil observasi di lapangan, sebagian besar peserta didik kelas V SDN Margahayu 08 Tahun Ajaran 2018-2019 menunjukkan pemahaman matematis yang rendah. Penelitian ini bertujuan untuk menerapkan strategi pembelajaran inkuiri berbantuan alat peraga "Dulok Kumisan" dalam meningkatkan pemahaman matematis. Metode penelitian yang digunakan yaitu eksperimen semu dengan rancangan penelitian nonequivalen control group design. Instrumen yang digunakan yaitu tes uraian dan lembar observasi pelaksanaan pembelajaran. Pengujian hipotesis pertama menggunakan uji beda rata-rata (data berasal dari distribusi normal dan homogen) sedangkan hipotesis kedua diuji dengan Mann Whitney U Test karena normalitas tidak terpenuhi tetapi berasal dari varians yang homogen. Hasil penelitian menunjukkan kemampuan pemahaman matematis peserta didik kelas eksperimen yang menerapkan strategi pembelajaran inkuiri berbantuan alat peraga "Dulok Kumisan" lebih baik daripada kelas kontrol yang menggunakan metode pembelajaran konvensional dan terdapat perbedaan peningkatan pemahaman matematis peserta didik kelas V SDN Margahayu 08 pada pokok bahasan volume kubus dan balok setelah diterapkan strategi pembelajaran inkuiri berbantuan alat peraga "Dulok Kumisan". Dengan demikian strategi pembelajaran inkuiri berbantuan alat peraga "Dulok Kumisan" dapat diterapkan untuk meningkatkan pemahaman matematis.
\end{abstract}

Kata Kunci: Strategi Pembelajaran Inkuiri, Kemampuan Pemahaman Matematis, Alat Peraga Volume Kubus dan Balok

\begin{tabular}{llll}
\hline Received & $: 2019-09-28$ & Approved & $: 2019-11-22$ \\
Reviesed & $: 2019-11-08$ & Published & $: 2019-12-07$ \\
\hline
\end{tabular}

(c) (7) (2) Jurnal Cakrawala Pendas is licensed under a Creative Commons Attribution-
ShareAlike 4.0 International License. 


\section{Pendahuluan}

Pembelajaran di sekolah dasar menuntut berbagai kompetensi yang harus dimiliki oleh peserta didik. Diantaranya peserta didik dituntut untuk memiliki kompetensi pemahaman matematis. Pemahaman matematis merupakan kemampuan dalam menjelaskan, menerapkan, membuktikan, mengaitkan suatu konsep/rumus/prinsip yang ada dalam pikirannya dengan konsep lainnya menjadi lebih bermakna (Susanto, 2013). Sejalan dengan Susanto, Lestari dan Ridwan menambahkan, kemampuan pemahaman matematis adalah kemampuan menyerap dan memahami ide-ide matematika (Lestari \& Mokhammad Ridwan Yudhanegara, 2015). Pemahaman matematis diperoleh pada saat pembelajaran yang mengarahkan peserta didik untuk memahami sesuatu yang mereka pelajari, mengetahui kapan dan di mana penggunaan ilmu tersebut. Pemahaman berbeda dengan hapalan, yakni proses pembelajaran yang hanya memberikan pengetahuan berupa teori-teori. Model pembelajaran dengan menghapal merupakan pembelajaran yang tidak efektif (Susanto, 2013). Hal tersebut dikarenakan dalam proses pembelajaran tidak memberikan makna bagi peserta didik. Keefektifan pembelajaran ditentukan oleh ada tidaknya proses pemahaman suatu ilmu pengetahuan.

Di sekolah dasar, kemampuan pemahaman matematis diberikan kepada peserta didik dalam mata pelajaran matematika, salah satunya pada kompetensi dasar geometri pokok bahasan volume kubus dan balok. Konsep-konsep dalam matematika terorganisasi secara sistematis, logis, dan hierarkis dari yang paling sederhana ke yang kompleks. Oleh karena itu, pembelajaran matematika perlu diberikan sejak usia sekolah dasar (Arifuddin, 2017). Menurut Rusgianto (Jarmita, 2012), terdapat empat kemampuan yang perlu dikuasai oleh peserta didik untuk memahami konsep geometri yaitu: proses mengidentifikasi kecukupan informasi, menginterpretasikan suatu konsep dengan model, diagram, dan simbol, menginterpretasikan solusi, menentukan solusi (rumus atau konsep) yang tepat untuk menyelesaikan masalah.

Akan tetapi, fakta yang ada mengungkapkan bahwa sebagian besar peserta didik di sekolah dasar masih mengalami kesulitan terutama dalam pemahaman konsep materi geometri (Nur'aeni, 2010). Sebelumnya, hasil survey Programme for International Student Assessment (PISA) 2000/2001 memperlihatkan lemahnya peserta didik dalam geometri, khususnya memahami ruang dan bentuk yaitu kesulitan dalam membayangkan suatu balok yang berongga (Suwadi dalam (Karim, 2011). Hasil pengamatan lain yang dilakukan di salah satu SDN di Surabaya, sering ditemukan ketidak telitian peserta didik dalam menerapkan rumus ke dalam soal geometri yang berbeda terutama pada penyelesaian soal volume kubus dan balok (Liandra \& Budiyono, 2015).

Lemahnya kemampuan pemahaman konsep gemometri didukung oleh hasil observasi peneliti terhadap SDN Margahayu 08 di Kabupaten Bandung yang menunjukkan sebagian besar peserta didik belum memahami konsep dasar geometri terutama volume kubus dan balok. Peserta didik masih kesulitan dalam mendefinisikan konsep volume kubus dan balok secara verbal dan tulisan. Hal tersebut sejalan dengan observasi awal penelitian lain yang menunjukkan peserta didik tidak mampu membedakan panjang, lebar, dan tinggi pada suatu bangun ruang, sehingga mereka kesulitan dalam menghitung volume bangun ruang tersebut (Ulia \& Sari, 2018). Proses pembelajaran pun belum menggunakan alat peraga yang konkret (Yeni, 2011). Padahal dengan menggunakan alat peraga peserta didik dapat terlibat secara aktif sebagai subjek pembelajaran, mengalami secara langsung sesuatu yang dipelajarinya, menemukan sendiri konsep-konsep yang dipelajarinya, dan membangun pengetahuannya berdasarkan pengalaman yang dimilikinya. 
Kemampuan pemahaman matematis dapat ditingkatkan dengan menerapkan strategi pembelajaran yang menekankan kepada proses mencari dan menemukan konsep. Peran peserta didik yaitu mencari dan menemukan sendiri materi pelajaran, sedangkan pendidik berperan sebagai fasilitator dan pembimbing peserta didik untuk belajar (Lahadisi, 2014). Salah satu upaya yang dapat dilakukan yaitu dengan menerapkan strategi pembelajaran inkuiri berbatuan alat peraga matematika dalam pembelajaran, yang dinamakan "Dulok Kumisan". Berdasarkan beberapa hasil penelitian menyimpulkan model inkuiri secara signifikan dapat meningkatkan hasil belajar peserta didik di Indonesia (Wena, 2011). Begitu pula hasil penelitian lain menyimpulkan terdapat perbedaan pemecahan masalah antara yang belajar menggunakan strategi inkuiri dengan pembelajaran konvensional (Andriani, 2016). Rata-rata hasil belajar peserta didik meningkatkan 15 poin dari sebelum diberikan perlakuan penerapan strategi pembelajaran inkuiri (Hamdani \& Islam, 2019). Berdasarkan penelitian terdahulu disimpulkan strategi pembelajaran inkuiri dapat meningkatkan hasil belajar peserta didik.

Penerapan strategi pembelajaran inkuiri berbantuan alat peraga yang sesuai dengan pokok bahasan yang disampaikan membantu peserta didik memvisualisasikan pokok bahasan yang abstrak menjadi konkret sehingga mempermudah mereka dalam memahami konsep matematika (Yeni, 2011). Alat peraga matematika yang digunakan dalam penelitian ini dinamakan "Dulok Kumisan". Alat peraga matematika "Dulok Kumisan" bersifat praktis dan mudah digunakan oleh peserta didik dengan cara memasukkan dadu ke dalam kubus dan balok yang terbuat dari mika transparan sehingga memudahkan dalam menghitung banyaknya isi dari kubus dan balok tersebut. Penggunaan alat peraga dalam pembelajaran matematika sesuai dengan perkembangan belajar menurut Jean Piaget yaitu peserta didik kelas V (usia 10-11 tahun) berada pada tahap operasi konkret (Piaget \& Inhelder, 2016). Pada tahap ini, peserta didik dapat memahami operasi (logis) dan menemukan konsep dengan bantuan benda-benda konkret.

Dengan demikian pembelajaran yang disajikan dengan menggunakan beragam metode, alat peraga, dan sumber belajar yang bervariasi dapat memotivasi peserta didik dalam belajar matematika, sehingga kompetensi-kompetensi dalam mata pelajaran matematika dapat tercapai dengan optimal, yang akhirnya peserta didik terampil dalam menerapkan konsepkonsep yang dipelajari dalam kehidupannya sehari-hari. Adapun tujuan penelitian ini adalah menerapkan strategi pembelajaran inkuiri berbantuan alat peraga "Dulok Kumisan" dalam meningkatkan pemahaman matematis peserta didik.

\section{Metode Penelitian}

Metode penelitian ini merupakan penelitian eksperimen semu (kuasi eksperimen). Desain penelitian yang digunakan yaitu Nonequivalen Control Group Design dengan kelompok eksperimen maupun kelompok kontrol tidak dipilih secara random. Desain Nonequivalen Control Group Design (Sugiyono, 2013) dapat terlihat pada Bagan 1 di bawah ini.

\begin{tabular}{|lll|}
\hline $\mathbf{O}_{1}$ & $\mathbf{X}$ & $\mathbf{O}_{2}$ \\
$\mathbf{O}_{1} \ldots \ldots \ldots \ldots \ldots \ldots . .$. & $\mathbf{O}_{2}$ \\
\hline
\end{tabular}

Bagan 1 Desain Penelitian

Keterangan

$\mathrm{X}$ : Perlakuan strategi pembelajaran inkuiri berbantuan alat peraga "DuloK Kumisan"

$\mathrm{O}_{1}$ : Pretest kelas eksperimen dan kelas kontrol

$\mathrm{O}_{2}$ : Posttest kelas eksperimen dan kelas kontrol 
Penelitian ini dilaksanakan di SDN Margahayu 08, Jalan Sadang No. 138 Margahayu Tengah, Kecamatan Margahayu Kabupaten Bandung. Populasi penelitian berjumlah 66 peserta didik yang terbagi ke dalam dua kelas yaitu 5A dan 5B. Sampel penelitian diambil dengan purposive sampling yaitu kelas $5 \mathrm{~B}$ dikarenakan sebagian besar peserta didik kelas 5B memiliki kemampuan matematis yang rendah.

Instrumen yang digunakan sebagai pengungkap data dalam penelitian ini yaitu soal tes untuk mengukur pemahaman matematis peserta didik kelas V SDN Margahayu 08 pada pokok bahasan volume kubus dan balok. Soal tes ini dikembangkan dari indikator pemahaman matematis yang diungkapkan oleh Salimi (Susanto, 2013) yang terdiri dari tujuh indikator. Adapun kisi-kisi soal tes kemampuan pemahaman matematis dapat dilihat pada Tabel 1.

Tabel 1. Kisi-Kisi Soal Tes Kemampuan Pemahaman Matematis

\begin{tabular}{|c|c|c|c|}
\hline Kompetensi Dasar & $\begin{array}{l}\text { Indikator Pencapaian } \\
\text { Kompetensi }\end{array}$ & Indikator Pemahaman Matematis & $\begin{array}{l}\text { No } \\
\text { Item } \\
\text { Soal }\end{array}$ \\
\hline \multirow{8}{*}{$\begin{array}{l}\text { 3.5 Menjelaskan, } \\
\text { dan menentukan } \\
\text { volume bangun } \\
\text { ruang dengan } \\
\text { menggunakan } \\
\text { satuan volume } \\
\text { (seperti kubus } \\
\text { satuan) serta } \\
\text { hubungan pangkat } \\
\text { tiga dengan akar } \\
\text { pangkat tiga. }\end{array}$} & \multirow[t]{2}{*}{$\begin{array}{ll}\text { 3.5.1 } & \begin{array}{l}\text { Memahami satuan } \\
\text { volume. }\end{array}\end{array}$} & $\begin{array}{l}\text { Mendefinisikan konsep secara verbal } \\
\text { dan tulisan }\end{array}$ & 3 \\
\hline & & $\begin{array}{l}\text { Membuat contoh dan non contoh } \\
\text { penyangkal }\end{array}$ & $\begin{array}{l}1 \mathrm{~A} \\
1 \mathrm{~B}\end{array}$ \\
\hline & \multirow[t]{2}{*}{$\begin{array}{ll}\text { 3.5.2 } & \text { Menganalisis unsur } \\
& \text { dan volume kubus. }\end{array}$} & $\begin{array}{l}\text { Mempresentasikan suatu konsep } \\
\text { dengan model, diagram, dan simbol }\end{array}$ & 2 \\
\hline & & $\begin{array}{l}\text { Mengubah suatu bentuk representasi } \\
\text { ke bentuk lain }\end{array}$ & 5 \\
\hline & $\begin{array}{l}\text { 4.5.1 Menyelesaikan } \\
\text { masalah yang berkaitan dengan } \\
\text { volume bangun ruang dengan } \\
\text { menggunakan satuan volume. }\end{array}$ & $\begin{array}{l}\text { Mengenal berbagai makna dan } \\
\text { interpretasi konsep. }\end{array}$ & $\begin{array}{l}6 \mathrm{~A} \\
6 \mathrm{~B}\end{array}$ \\
\hline & \multirow{2}{*}{$\begin{array}{l}\text { 3.5.3. Menganalisis unsur } \\
\text { dan volume balok } \\
4.5 .2 \\
\text { Menyelesaikan masalah yang } \\
\text { berkaitan dengan volume } \\
\text { kubus dengan menggunakan } \\
\text { satuan volume melibatkan } \\
\text { pangkat tiga. }\end{array}$} & $\begin{array}{l}\text { Mempresentasikan suatu konsep } \\
\text { dengan model, diagram, dan simbol }\end{array}$ & 4 \\
\hline & & $\begin{array}{l}\text { Mengidentifikasi sifat-sifat suatu } \\
\text { konsep dan mengenal syarat-syarat } \\
\text { yang menentukan suatu konsep }\end{array}$ & 7 \\
\hline & $\begin{array}{l}\text { 3.5.2 Menganalisis unsur } \\
\text { dan volume kubus. }\end{array}$ & $\begin{array}{l}\text { Membandingkan dan membedakan } \\
\text { konsep-konsep. }\end{array}$ & $\begin{array}{l}8 \mathrm{~A}, \mathrm{~B} \\
\mathrm{C} \\
9 \mathrm{~A}, \mathrm{~B} \\
\mathrm{C}\end{array}$ \\
\hline
\end{tabular}

Sebelum soal tes digunakan untuk pretest dan Rencana Pelaksanaan Pembelajaran (RPP) untuk perlakuan, terlebih dahulu dilakukan analisis (judgment instrument) oleh pakar/dosen ahli dalam bidang pembelajaran matematika. Instrumen yang telah dianalisis oleh pakar kemudian direvisi sesuai dengan saran dan masukan dari ahli. Adapun hasil analisis ahli dinyatakan RPP dengan menggunakan strategi pembelajaran inkuiri berbantuan alat peraga "Dulok Kumisan" layak digunakan untuk meningkatkan pemahaman matematis peserta didik kelas V SDN Margahayu 08 pada pokok bahasan volume kubus dan balok dan soal tes layak diuji cobakan untuk mengetahui tingkat validitas dan reliabilitasnya.

Uji validitas item pertanyaan menggunakan uji korelasi Pearson Product Moment dengan bantuan SPPS 16.0. Nilai $r_{x y}$ yang diperoleh kemudian diuji signifikansinya dengan cara membandingkan antara nilai $r_{x y}$ dan nilai $r_{\text {tabel }}$ product moment untuk $\mathrm{N}=28$ dan taraf 
signifikansi $\alpha=0,05$, yaitu $r_{28(0,05)}=0,374$. Jika $r_{x y} \geq r_{\text {tabel }}$, maka item tersebut valid. Adapun hasil uji validitas tiap soal item soal tes kemampuan pemahaman matematis yaitu 13 item soal dinyatakan valid dan 2 item soal dinyatakan tidak valid. Item soal yang tidak valid kemudian direvisi.

Uji reliabilitas dilakukan untuk mengetahui tingkat kestabilan. Uji reliabilitas instrumen menggunakan koefisien reliabilitas Alpha Cronbach. Adapun hasil uji reliabilitas diperoleh skor 0,733 artinya derajat kestabilan tergolong tinggi.

Teknik pengumpulan data pada penelitian ini adalah berupa tes berbentuk soal uraian untuk mengukur pemahaman matematis peserta didik sekolah dasar pada pokok bahasan volume kubus dan balok. Tes uraian digunakan untuk mengetahui jawaban responden yang sifatnya terbuka dan dianalisis tingkat pemahaman matematis sampel yang diteliti. Instrumen yang digunakan yaitu lembar soal berupa tes uraian yang digunakan untuk pretest dan posttest.

Analisis data dilakukan terhadap hasil tes (pretest dan posttest) yang dilakukan secara individual terhadap peserta didik kelas V SDN Margahayu 08 tentang kemampuan pemahaman matematis dalam pokok bahasan volume kubus dan balok. Selanjutnya dilakukan pengolahan analisis statistik dalam beberapa tahap pengujian yaitu uji prasyarat (uji normalitas dan uji homogenitas), Uji-T (jika normalitas sampel dan homogenitas terpenuhi) atau Uji Mann Whitney (jika normalitas sampel dan homogenitas tidak terpenuhi) dan uji gain.

\section{Hasil dan Pembahasan}

Strategi pembelajaran inkuiri berbantuan alat peraga "Dulok Kumisan" untuk meningkatkan pemahaman matematis peserta didik kelas V SDN Margahayu 08 diterapkan selama tiga kali pertemuan pada pokok bahasan volume kubus dan balok. Pertemuan pertama, peserta didik dapat menemukan kembali rumus volume kubus dengan benar. Pertemuan kedua, peserta didik dapat menemukan kembali rumus volume balok dengan benar. Pertemuan ketiga, peserta didik dapat menyelesaikan masalah yang berkaitan dengan volume bangun ruang dengan menggunakan satuan volume.

Lembar obserasi guru digunakan untuk mengamati aktivitas pembelajaran yang dilakukan guru dalam melaksanakan langkah-langkah strategi pembelajaran inkuiri berbantuan alat peraga "Dulok Kumisan". Rekapitulasi analisis aktivitas guru dalam melaksanakan langkah-langkah pembelajaran inkuiri berbantuan alat peraga "Dulok Kumisan" setiap pertemuan mengalami peningkatan. Pertemuan pertama mencapai 55\% kategori cukup, pertemuan kedua mencapai $72 \%$ kategori cukup, dan pertemuan ketiga mencapai $80 \%$ kategori baik. Oleh karena itu, langkah-langkah strategi pembelajaran inkuiri berbantuan alat peraga "Dulok Kumisan" dilaksanakan oleh guru dengan baik.

Sebelum dilaksanakan perlakuan, terlebih dahulu dilaksanakan pretest untuk mengetahui kemampuan pemahaman matematis awal. Adapun hasil pretest kelas eksperimen menunjukkan nilai tertinggi adalah 66 , nilai terendah adalah 2 , dan nilai rata-rata adalah 39,39. Kelas kontrol menunjukkan nilai tertinggi adalah 76 , nilai terendah adalah 16 , dan nilai rata-rata adalah 45,82. SDN Margahayu 08 menetapkan nilai KKM mata pelajaran matematika adalah 70 . Tidak ada peserta didik yang memperoleh nilai di atas KKM. Hasil tersebut menunjukkan seluruh peserta didik kelas V SDN Margahayu 08 mempunyai pemahaman matematis yang rendah pada pokok pembahasan volume kubus dan balok. Oleh karena itu, diperlukan suatu upaya melalui penerapan strategi pembelajaran yang tepat dengan bantuan alat peraga yang sesuai dengan materi yang diajarkan sehingga peserta didik mampu memahami konsep secara utuh dan bermakna. 
Setelah diberikan perlakukan dengan penerapan strategi pembelajaran inkuiri berbantuan alat peraga "Dulok Kumisan" diadakan posttest dengan soal yang sama. Adapun hasil posttest pemahaman matematis peserta didik kelas V SD Margahayu 08 kelas eksperimen menunjukkan nilai tertinggi adalah 98 , nilai terendah adalah 40 , dan nilai rata-rata adalah 72,12 . 24 dari 33 peserta didik atau 73\% yang memperoleh nilai di atas KKM. Hanya 9 orang yang memperoleh nilai di bawah KKM. Kelas kontrol menunjukkan nilai tertinggi adalah 88, nilai terendah adalah 22 , dan nilai rata-rata adalah 52,97 . Hal tersebut menunjukkan sebagian besar peserta didik kelas ekserimen menunjukkan peningkatatan dalam kemamuan pemahaman matematisnya terutama pada pokok pembahasan volume kubus dan balok. Dengan demikian penerapan strategi pembelajaran inkuiri dengan bantuan alat peraga "Dulok Kumisan" dapat meningkatkan pemahaman matematis peserta didik.

Penelitian ini menguji dua hipotesis. Hipotesis pertama yaitu kemampuan pemahaman matematis peserta didik kelas eksperimen yang menerapkan strategi pembelajaran inkuiri berbantuan alat peraga "Dulok Kumisan" lebih baik daripada kelas kontrol yang menggunakan metode pembelajaran konvensional. Data yang digunakan untuk menguji hipotesis tersebut yaitu nilai selisih antara hasil pretest dan posttest pada kelas kontrol dan kelas eksperimen. Untuk membuktikan apakah penerapan strategi pembelajaran inkuiri berbantuan alat peraga "Dulok Kumisan" lebih baik dibanding dengan metode konvesional maka data perlu diuji secara statistik dengan uji beda rata-rata (uji t) dengan prasyarat data tersebut harus berasal dari populasi normal dan homogen. Oleh karena itu perlu diuji normalitas dan homogenitas.

Uji normalitas menggunakan Shapiro Wilk dengan taraf signifikansi $(\alpha)$ sebesar 0,05 . Hasil uji normalitas selisih nilai pretest-posttest diperoleh nilai signifikansi kelas kontrol sebesar 0,360 dan kelas eksperimen sebesar 0,576. Karena nilai signifikansi lebih besar dari 0,05 maka menurut kriteria uji $\mathrm{H}_{0}$ diterima yang artinya data selisih nilai pretest kelas eksperimen dan kelas kontrol berdistribusi normal. Selanjutnya dilakukan uji homogenitas. Uji homogenitas dilakukan untuk mengetahui masing-masing data yang diperoleh memiliki varians populasi yang homogen (sama) atau tidak. Uji statistik yang digunakan adalah uji Levene's dengan taraf signifikansi $(\alpha)$ sebesar 0,05 . Hasil perhitungan diperoleh nilai signifikansi sebesar 0,489. Karena nilai signifikansi lebih dari 0,05 maka $\mathrm{H}_{0}$ diterima. Hal ini menunjukkan bahwa data selisih nilai pretest-posttest kelas eksperimen dan kelas kontrol berasal dari varians yang homogen.

Setelah dilakukan uji normalitas dan homogenitas, maka diketahui bahwa data selisih nilai pretest-posttest kelas eksperimen dan kontrol berdistribusi normal dan homogen. Selanjutnya menguji perbedaan dua rata-rata dilakukan dengan uji t dengan taraf signifikansi $(\alpha)$ sebesar 5\% $(0,05)$. Hasil perhitungan menunjukkan nilai sig. (2-tailed) atau $\mathrm{p}$ value sebesar 0,000 lebih kecil dari $\alpha=0,05$, maka $\mathrm{H}_{0}$ ditolak atau $\mathrm{H}_{1}$ diterima. Berdasarkan pembuktian tersebut, disimpulkan kemampuan pemahaman matematis peserta didik kelas eksperimen yang menerapkan strategi pembelajaran inkuiri berbantuan alat peraga "Dulok Kumisan" lebih baik daripada kelas kontrol yang menggunakan metode pembelajaran konvensional.

Pembuktian hipotesis kedua yang berbunyi terdapat perbedaan peningkatkan pemahaman matematis peserta didik kelas V SDN Margahayu 08 pada pokok bahasan volume kubus dan balok setelah diterapkan strategi pembelajaran inkuiri berbantuan alat peraga "Dulok Kumisan" perlu dilakukan uji normalitas dan homogenitas sebagai prasyarat mengetahui perbedaan peningkatan. Data yang digunakan untuk membuktikan perbedaan peningkatan adalah data nilai N-Gain yang ternormalisasi. Setelah asumsi distribusi normalitas sampel dan homogenitas terpenuhi maka dilakukan uji perbedaan rata-rata. Jika asumsi distribusi 
normalitas sampel dan homogenitas tidak terpenuhi maka dilakukan Uji Mann Whitney karena menguji dua kelompok independen atau saling bebas.

Uji normalitas dilakukan untuk mengetahui indeks_gain yang diperoleh dari kelas eksperimen dan kelas kontrol berasal dari populasi normal atau tidak. Uji statistik yang digunakan adalah uji normalitas menggunakan Shapiro Wilk dengan taraf signifikansi $(\alpha)$ sebesar 0,05. Berdasarkan hasil perhitungan diperoleh nilai signifikansi kelas kontrol sebesar 0,000 dan kelas eksperimen sebesar 0,200. Kelas eksperimen mempunyai nilai signifikansi lebih besar dari 0,05 maka menurut kriteria uji $\mathrm{H}_{0}$ diterima yang artinya data indek-gain kelas eksperimen berdistribusi normal. Tetapi, kelas kontrol memempunyai nilai signifikansi lebih kecil dari 0,05 maka menurut kriteria uji $\mathrm{H}_{0}$ ditolak, artinya data indeks-gain kelas kontrol tidak berdistribusi normal. Oleh karena itu, pengujian hipotesis kedua ini tidak dapat menggunakan uji beda rata-rata, tetapi menggunakan Mann Whitney U Test. Sebagai syarat pengujian Mann Whitney U Test perlu data yang homogen.

Uji homogenitas dilakukan untuk mengetahui masing-masing data yang diperoleh memiliki varians populasi yang homogen (sama) atau tidak. Uji statistik yang digunakan adalah uji Levene's dengan taraf signifikansi $(\alpha)$ sebesar 0,05. Berdasarkan hasil perhitungan diperoleh nilai signifikansi sebesar 0,196. Karena nilai signifikansi lebih dari 0,05 maka $\mathrm{H}_{0}$ diterima. Hal ini menunjukkan bahwa data indeks-gain kelas eksperimen dan kelas kontrol berasal dari varians yang homogen.

Pengujian hipotesis kedua ini dengan menggunakan Mann Whitney U Test karena data berasal dari distribusi tidak normal dan homogen. Dengan menggunakan taraf signifikansi $(\alpha)$ sebesar 5\% (0,05). Hasil Mann Whitney Test menunjukkan mean rank atau rata-rata peringkat tiap kelompok yaitu pada kelas eksperimen rerata peringkatnya 45,39 lebih tinggi dari pada rerata peringkat kelas kontrol, yaitu 21,61. Nilai Mann-Whitney sebesar 152 dan nilai Wilcoxon sebesar 713. Apabila dikonversikan ke nilai Z maka sebesar -5,048. Adapun nilai signifikasinya sebesar 0,000 lebih kecil dari $\alpha=0,05$, maka $\mathrm{H}_{0}$ ditolak atau $\mathrm{H}_{1}$ diterima. Berdasarkan pembuktian tersebut, disimpulkan terdapat perbedaan peningkatkan pemahaman matematis peserta didik kelas V SDN Margahayu 08 pada pokok bahasan volume kubus dan balok setelah diterapkan strategi pembelajaran inkuiri berbantuan alat peraga "Dulok Kumisan"

Pemahaman matematis merupakan salah satu kompetensi pada mata pelajaran matematika yang harus dikuasai oleh peserta didik sekolah dasar. Pemahaman matematis adalah suatu proses mental untuk menyerap, memahami ide-ide, menggambarkan suatu pengertian, sehingga dapat mengkomunikasikan suatu makna yang terkandung dalam informasi ke dalam bentuk lain yang lebih berarti. Konsep-konsep dalam matematika terorganisasi secara sistematis, logis, dan hierarkis dari yang paling sederhana ke yang kompleks. Dengan kata lain, pemahaman dan penguasaan suatu materi atau konsep merupakan prasyarat untuk menguasi materi atau konsep selanjutnya (Susanto, 2013). Oleh sebab itu, kemampuan pemahaman matematis merupakan hal yang sangat fundamental dalam pembelajaran matematika agar belajar menjadi lebih bermakna.

Tujuan umum penelitian ini yaitu penerapan strategi pembelajaran inkuiri berbantuan alat peraga "Dulok Kumisan" dalam meningkatkan pemahaman matematis peserta didik kelas V SDN Margahayu 08 Tahun Ajaran 2018-2019 pada pokok bahasan volume kubus dan balok. Penerapan suatu strategi pembelajaran berbantuan alat peraga yang tepat dapat membantu dalam meningkatkan pemahaman matematis peseta didik (Yeni, 2011). Strategi pembelajaran inkuiri berbantuan alat peraga "Dulok Kumisan" ialah cara dan seni pembelajaran yang menekankan proses berpikir secara kritis dan analitis yang didasari oleh 
keingintahuan untuk mencari dan menemukan konsep materi pelajaran untuk mencapai hasil pembelajaran yang bermakna dengan bantuan alat peraga "Dulok Kumisan". Langkahlangkah pembelajaran inkuiri berbatuan alat peraga "Dulok Kumisan" yaitu orientasi, merumuskan masalah, mengajukan hipotesis, mengumpulkan data, menguji hipotesis, dan merumuskan kesimpulan (Sanjaya, 2008).

Berdasarkan rekapitulasi analisis aktivitas guru dalam melaksanakan langkah-langkah pembelajaran inkuiri berbantuan alat peraga "Dulok Kumisan" setiap pertemuan mengalami peningkatan. Pertemuan pertama mencapai 55\% kategori cukup, pertemuan kedua mencapai $72 \%$ kategori cukup, dan pertemuan ketiga mencapai 80\% kategori baik. Oleh karena itu, langkah-langkah strategi pembelajaran inkuiri berbantuan alat peraga "Dulok Kumisan" dilaksanakan oleh guru dengan baik dan dapat meningkatkan aktivitas pembelajaran peserta didik. Peserta didik belajar secara langsung dengan cara memanifulasi alat peraga "Dulok Kumisan", mencari dan menemukan sendiri rumus volume kubus dan balok sehingga pembelajaran lebih bermakna. Hal ini diperkuat oleh Sanjaya, yang menyatakan keunggulan penerapan strategi pembelajaran inkuiri yaitu (a) strategi pembelajaran inkuiri menekankan kepada pengembangan aspek kognitif, afektif, dan psikomotor secara seimbang, sehingga pembelajaran melalui strategi ini dianggap lebih bermakna. (b) strategi pembelajaran inkuiri dapat memberikan ruang kepada peserta didik untuk belajar sesuai dengan gaya belajar mereka. (c) strategi pembelajaran inkuiri merupakan strategi yang dianggap sesuai dengan perkembangan psikologi belajar modern yang menganggap belajar adalah proses perubahan tingah laku berkat adanya pengalaman. (d) keuntungan lain adalah strategi pembelajaran ini dapat melayani kebutuhan peserta didik yang memiliki kemampuan di atas rata-rata. Artinya, peserta didik yang memiliki kemampuan belajar bagus tidak akan terhambat oleh peserta didik yang lemah dalam belajar (Sanjaya, 2008).

Strategi pembelajaran inkuiri berbantuan alat peraga "Dulok Kumisan" diterapkan di kelas eksperimen (5B) sedangkan kelas kontrol (5A) menggunakan metode pembelajaran konvensional. Sebelum diberikan perlakuan, kelas eksperimen dan kelas kontrol diberikan pretest. Rata-rata pretest kelas eksperimen sebesar 39, dan kelas kontrol sebesar 46. Setelah perlakuan diberikan posttest, kelas ekperimen memperoleh rata-rata sebesar 72 dan kelas kontrol sebesar 53. Berdasarkan pengolahan dan analisis data kedua kelas tersebut berdistribusi normal dan homogen. Selanjutnya menguji perbedaan dua rata-rata, menunjukkan nilai sig. (2-tailed) atau p value sebesar 0,000 lebih kecil dari $\alpha=0,05$, maka H0 ditolak atau $\mathrm{H} 1$ diterima, disimpulkan bahwa kemampuan pemahaman matematis peserta didik kelas eksperimen yang menerapkan strategi pembelajaran inkuiri berbantuan alat peraga "Dulok Kumisan" lebih baik daripada kelas kontrol yang menggunakan metode pembelajaran konvensional. Kemudian untuk mengetahui perbedaan peningkatan dilakukan Mann Whitney-U Test karena data berasal dari distribusi tidak normal tetapi homogen. Hasilnya menunjukkan mean rank atau rata-rata peringkat tiap kelompok yaitu pada kelas eksperimen rerata peringkatnya 45,39 lebih tinggi dari pada rerata peringkat kelas kontrol, yaitu 21,61. Nilai Mann-Whitney sebesar 152 dan nilai Wilcoxon sebesar 713. Apabila dikonversikan ke nilai $\mathrm{Z}$ maka sebesar $-5,048$. Adapun nilai signifikasinya sebesar 0,000 lebih kecil dari $\alpha=0,05$, maka $\mathrm{H}_{0}$ ditolak atau $\mathrm{H}_{1}$ diterima, disimpulkan terdapat perbedaan peningkatkan pemahaman matematis peserta didik kelas V SDN Margahayu 08 pada pokok bahasan volume kubus dan balok setelah diterapkan strategi pembelajaran inkuiri berbantuan alat peraga "Dulok Kumisan".

Berdasarkan hasil pengujian hipotesis tersebut disimpulkan bahwa strategi pembelajaran inkuiri berbantuan alat peraga "Dulok Kumisan" dapat meningkatkan pemahaman matematis 
peserta didik. Hasil penelitian ini senada dengan penelitian yang dilakukan oleh (Arifuddin, Alfiani, \& Hidayati, 2018), (Purwasih, 2015), (Anggareni, N. P. Ristiati, \& N. L. P. M. Widiyanti, 2013), (Sochibin, Dwijananti, \& Marwoto, 2009) yang mengungkapkan bahwa pembelajaran inkuiri dapat meningkatkan aktivitas pembelajaran (guru dan peserta didik) serta berpengaruh terhadap peningkatan kemampuan pemecahan masalah, berpikir kritis, dan pemahaman konsep peserta didik.

\section{Simpulan}

Berdasarkan tujuan penelitian yang telah dibuktikan dengan hasil uji hipotesis dan hasil analisis data, maka dapat disimpulkan kemampuan pemahaman matematis peserta didik kelas eksperimen yang menerapkan strategi pembelajaran inkuiri berbantuan alat peraga "Dulok Kumisan" lebih baik daripada kelas kontrol yang menggunakan metode pembelajaran konvensional dan terdapat perbedaan peningkatan pemahaman matematis peserta didik kelas V SDN Margahayu 08 pada pokok bahasan volume kubus dan balok setelah diterapkan strategi pembelajaran inkuiri berbantuan alat peraga "Dulok Kumisan".

\section{Daftar Pustaka}

Astuti, Y, and B setiawan. 2013. "Pengembangan Lembar Kerja Siswa (LKS) Brbasis Pendekatan Inkuiri Terbimbing Dalam Pembelajaran KooPeratif Pada Materi Kalor." pendidikan IPA Indonesia 2(1): 88-92.

Budisetyawan, S. 2012. "Pengembangan LKS IPA Terpadu Berbasis Inkuiri Terbimbing Pada Tema Sistem Kehidupan Dalam Tumbuhan Kelas VIII Di SMP N 2 Playen." Pendidikan IPA FMIPA UNY 1(4): 1-6.

Chandra, Mayarnimar, and M. Habibi. 2018. "Keterampilan Membaca Dan Menulis Permulaan Menggunakan Model Vark Untuk Siswa Sekolah Dasar." Jurnal Inovasi Pendidikan Dan Pembelajaran Sekolah Dasar 2(1): 72-80. http://ejournal.unp.ac.id/index.php/jippsd/article/view/100050.

Fauziah, Muhardila. 2018. "Meningkatkan Keterampilan Membaca Intensif Melalui Metode Group Investigationdi Kelas IIIB SDN 05 VI Suku." Cakrawala Pedagogik 2(2): 169-75. http://stkip.syekhmanshur.ac.id/jurnal/index.php/CP/article/view/83.

Habibi, M., and Chandra. 2018. "Strategi Direct Writing Activity Sebagai Upaya Peningkatan Keterampilan Menulis Deskripsi Bagi Siswa Kelas II SD." Jurnal Inovasi Pendidikan Dan $\begin{array}{llll}\text { Pembelajaran Sekolah Dasar } & \text { ISSN }\end{array}$ http://103.216.87.80/index.php/jippsd/article/view/100032.

Habibi, M, Chandra, R Mahyuddin, and S Hendri. 2018. "Validity of Teaching Materials for Writing Poetry Based on Creative Techniques in Elementary Schools." Mimbar Sekolah Dasar 5(3): 145-54. http://ejournal.upi.edu/index.php/mimbar/article/view/14501.

Muhammadi, Taufina, and Chandra. 2018. "Literasi Membaca Untuk Memantapkan Nilai Sosial Siswa Sd." Litera $17(2)$ : 202-12. https://journal.uny.ac.id/index.php/litera/article/view/16830.

N, Resmini, and Dkk. 2009. Pembinaan Dan Pengembangan Pembelajaran Bahasa Dan Sastra Indonesia. Bandung: UPI PRESS.

Prastowo, Andi. 2014. Panduan Kreatif Membuat Bahan Ajar Inovatif. Yogjakarta: Diva Press. 
Rahayu, P, S Mulyani, and Miswadi S.S. 2012. "Pengembangan Pembelajaran IPA Terpadu Dengan Mengunakan Model Pembelajaran Problem Base Melalui Lesson Study." pendidikan IPA Indonesia 1(1): 63-70.

Sasmito, luncana faridhoh, and Ali Mustadi. 2015. "Pengembangan Lembar Kerja Peserta Didik Temtik Integratif Berbasis Pendidikan Karakter Pada Peserta Didik Sekolah Dasar." Pendidikan Karakter 5(1): 70-81.

Siskandar. 2017. "Analysis Of The Role Of Teacher And Madrasah Leadership In Implementing." 19(2): 149-58. file:///C:/Users/usergb/Downloads/12194-29239-1PB.pdf.

Sugiyono. 2009. Metode Penelitian Kuantitatif, Kualitatif Dan R\&D. Bandung: Alfabet.

Tarigan, Henry Guntur. 2009. Pengajaran Kompetensi Bahasa. Bandung: Angkasa.

Taufina, and Chandra. 2017. "Developing The Big Questions And Bookmark Organizers (Bqbo) Strategy-Based Literacy Reading Learning Materials In The 4th Grade Of Elementary School." In 9th International Conference for Science Educators and Teachers (ICSET), Atlantis Press, 857-64. https://www.atlantis-press.com/proceedings/icset$17 / 25886637$.

Tedjawati, J.M. 2011. "Peningkatan Kompetensi Guru Melalui Lesson Study: Kasus Di Kabupaten Bantul." Jurnal pendidikan dan kebudayaan 17: 480-89.

Thobroni, M, and Arif Musthoafa. 2011. Belajar Dan Pembelajaran Pengembangan Wacana Dan Praktik Pembelajaran Dalam Pembangunan Nasional. Yogyakarta: Ar-Ruzz Media.

Trianto. 2010. Mendesain Model Pembelajaran Inovatif-Progresif (Konsep, Landasan Implementasi Pada Kurikulum Tingkat Satuan Pendidikan). Jakarta: Prenada Media Group.

Widhiartha, and Dkk. 2008. Lesson Study Sebuah Upaya Peningkatan Mutu Pendidik Pendidik Non Formal. Surabaya: Prima Printing. 